\title{
Trends and Dynamics in Retail Industry: Focus on Relational Proximity ${ }^{1}$
}

\author{
Marcello Sansone ${ }^{1}$, Annarita Colamatteo ${ }^{2}$ \\ ${ }^{1}$ Associate Professor in Marketing, University of Cassino and Southern Lazio, 03043 Cassino - Via Sant'Angelo, \\ loc. Folcara, Italy \\ ${ }^{2}$ PhD Student, University of Cassino and Southern Lazio, 03043 Cassino - Via Sant'Angelo, loc. Folcara, Italy \\ Correspondence: Marcello Sansone, Associate Professor in Marketing, University of Cassino and Southern Lazio, \\ 03043 Cassino - Via Sant'Angelo, loc. Folcara, Italy. E-mail: m.sansone@ unicas.it
}

Received: November 19, 2016

Accepted: January 17, 2017

Online Published: January 22, 2017

doi:10.5539/ibr.v10n2p169

URL: http://dx.doi.org/10.5539/ibr.v10n2p169

\begin{abstract}
This paper aims to analyze the dynamics of retail innovation and store format, in particular underlining the variables that have led retailers in a return to the concept of neighbourhood, understood as relational proximity to the consumer.

In particular, it shows that the concept of neighbourhood is evolving towards new patterns that deviate from previous interpretations of literature that identified under a purely dimensional aspect; today the format of neighbourhood is synonymous with relational proximity with the consumer and this assumption leads to consider proximity also a large store. The economic crisis and the changing lifestyles of consumers have brought independent and associate retailers to reinterpret its format by thinking like a basket of attributes, which includes further services in order to satisfy better consumer needs. The work shows that retail innovation is oriented towards the concept of relational proximity, whose main strength is the ability of the entrepreneur to be in direct relationship with its customers and to be able to get and interpret changes in the market, thus creating a sustainable competitive advantage.
\end{abstract}

Keywords: retail innovation, retail marketing, neighbourhood store, relational proximity, format innovation

\section{Introduction}

The reference literature ascribes increasing importance to the issue of retail innovation, with particular reference to the tendency to innovate the format by resuming a concept of proximity that goes beyond the simple spatial and dimensional characteristics, but that focuses on establishing relationships of loyalty with the consumer. In the first part of the work there is a review of the most relevant literature on the topic of retailing innovation (Pastore, Pellegrini, Ravazzoni, 2001; Castaldo, 2008; Alexander, Phillips, Shaw, 2008; Fornari, 2009; Lugli, 2009; Castaldo, Mauri, 2010; Quinn, Barry, 2013) understood as a morphogenetic process behind evolution of retailing techniques in time and space, not sequential and not continuous(Sansone, 2002), and - briefly - on the main theories that explain how innovation processes arise in terms of concept and format, with the increasing complexity of retail organization, with the increase of its bargaining power in the distribution channel and of the horizontal and vertical competition.

It's relevant - for scholars and for managers - to understand the reasons why commercial enterprises innovate, which are generally summarized in three main categories (Environmental factors, demand factors and supply factors) (Cardinali, 2009); it is equally important to understand how these factors influence the emergence of new distribution formulas and how much innovation is perceived by the consumer.

The case analysed is UniCoopFirenze that in recent years has revised the concept of superstores and simultaneously has reduced hypermarkets in its portfolio of types of stores: at the end of March 2015 it has renovated a supermarket in Tuscany, launching a new concept of neighbourhood, looking for a target, the elderly,

\footnotetext{
${ }^{1}$ Although this paper represents the result of communal considerations of the Authors, the paragraphs 1,2 and 2.1 have been elaborated by Marcello Sansone; the paragraphs 3, 4, 4.1, 4.2 and the conclusions have been elaborated by Annarita Colamatteo.
} 
which is becoming increasingly important, making an innovation of concept that reproduces a real market.

\section{The Evolution of Retail Innovation: An Overview}

The issue of retail innovation and its complexity determine the need to investigate this topic with a holistic approach. In general, it can identify different distinctive elements of innovation: the production of a discontinuity in the effects of business conduct; the derivation from careful planning in the phase of design and/or implementation; the appreciation - or, at least, the acceptance -by the market, or otherwise, by the recipients of the proposed change, that otherwise results in a sporadic and unsuccessful attempt.

The different distinctive elements of business innovation just described contribute also to avoid creating misunderstandings and unfounded beliefs, such as those who see innovation as a solution for past inefficient and customary management or as a product of fortuitous and exceptional events.

Rather, each operator must be aware that be innovative and researching innovation require intensive resources and produce more often negative and ruinous outcomes; nevertheless, innovation, for the many reasons set out above, is an increasingly important objective, and remains, in any case, the most direct, rapid and perceivable manner to achieve competitive advantages.

In line with the qualification of business innovation, the commercial innovation must be understood as the morphogenetic process behind a not sequential and continuous evolution, of distributive technique in time and space. It's important that the store is a central element of the retailer's offer; it can therefore be argued that retail innovation is the store innovation that is a type of store essentially unpublished introduced on market, diversified or even differentiated with respect to the types already observed (Sansone, 2004).

Among the advanced reconstructions from the early twentieth century, stand out those of Schumpeter, who - in his first proposition - significantly emphasizes the voluntary feature, by electing the innovation as a crucial vehicle of profitability and of growth of the enterprise and by identifying the cause in the search of the maximum production efficiency. However, later he revises its position and proposes a reversal of the relationship between profit and innovative capacity; so the latter becomes a subset of the strongest and established enterprises that are able to consolidate its market position by counteracting the natural obsolescence of the technical and productive solutions.

No less important is the proposition formulated by Cyert and March, which locates in the competitive pressure the primary factor propelling innovation; with this a company seeks to achieve the acquisition of a competitive advantage that, however, does not crystallize in a monopoly position, because of increasing of capital mobility and of transferability of technologies.

However, both theories mentioned confirm the qualification of business innovation previously exposed, followed by the corollary of orderliness and planning as conditions for the success of the renewal.

In other words, the arguments advanced remove the myth of innovation as an inefficient and customary past management; in fact the change cannot be a contingent solution for the enterprise, especially for those that are in difficulty or poorly competitive.

On the contrary the innovation must be a permanent tension, which uses the resources accumulated during periods of increased vitality. So, it arrives to the vision of aptitude at the change as a modusoperandi typical of the individual enterprise, whose aim is precisely to prevent the phenomena of crystallization of management on paradigms not appropriate to demand and to the competitive environment and tosearch for better performance.

Referring to marketing channels, the concept of innovation on the one hand must be seen as strategic activity for both industrial and distribution firms to acquire a competitive advantage, and on the other hand, it should be seen as a changing process of the economic function of the distribution systems (Musso, 2010).

During almost a century several theories on the evolution of retail innovation have been proposed. The main lines of research on the one hand analyzed the relationships between industries and retailers, focusing on observation of industrial manufacturer and of its marketing mix. The retail distribution system was considered a mere instrument, used by the industry, for the development of marketing policies needed to place its products on the consumer market. On the other hand it has analyzed the evolutionary dynamics of the distribution system. In some cases the subject of study was the entire system, in other the distribution channel, focusing on the intermediaries; in still other cases, it has been treated specifically the distribution format including those relating to the retail.

As for the second line of research, various authors propose a schematic summary consisting essentially of three sections: descriptive approach; mechanistic and evolutionary approach; multi-criteria evolutionary approach (Sansone, 2006). 
The descriptive approach analyzes the different retail formula identifying some possible criteria for classification. The main investigations carried out in this context limited to a few factors the basis of classification of the institutions of the retail, differentiating them by the use of a discriminating best-known research refer to the type of product sold, to the behaviour of consumers or to the sales strategies adopted. These studies do not provide useful indications for the identification of an evolutionary paradigm that is able to explain the present structure and even more predict the transformations that the retail system may undergo in the future.

The descriptive analysis, limiting itself to classify the various types of retail formulas, does not respond to the needs that industrial and commercial companies have in relation to the possibility of prediction of the occurrence of new formulas of sale. The need to identify a valid component induced researchers to be interested in elements, derived from the economic and social environment. These elements while having a less immediate relationship with the business sector should be able to interact with it and represent, therefore, the incentive to clarify the change. In summary the need shared is to replace the merely descriptive analysis approach with something more complex. The real goal is summed up in a forecast of a new sales formula.

The first models analyzed, able to explain in a historical perspective the evolution of the retail distribution system, were mechanistic. This, probably, in virtue of the theories of causality active in those years and meaningful solutions proposed by them, with regard to different areas of knowledge. Essentially the mechanistic evolutionary approach is concerned with identifying the cause that gives to retail the evolutionary dynamics and tries to predict the future transformations, by designing them as the necessary result of certain conditioning factors that can be summarized in a synthetic and efficient "cause".

Among these, the theory of "big disturbance" considers the so-called innovative competition as efficient cause of the evolution of the distribution system.

To understand the limits of validity it must first accept this assumption: maintaining the usual management techniques as a part of a static distribution system prevents the establishment of a competitive environment and therefore the contention of the market remains stationary. So, where is manifest a competition it can implicitly consider that the business environment is evolving.

Said that, according to Schumpeter, in addition to traditional competition coming from the other retailer like those already on the market, it can find, as a factor for innovation, the competition resulting from the entry into the market of new organizations with characteristics that result in an imitative large process.

The innovative strength possessed by the new distributive institution, causes a disruption of the market and the unbalanced of the distribution system as a whole. Consequently, it arises a process of rearrangement that sees, by the new entrants in the market and by those already present, an increasing willpower to achieve a overall commercial proposal that is satisfactory to the consumer. The course developed by the operators, the actions, the corrective and rapid adjustments help to create and amplify progressively the "big disturbance." Therefore, new organizational models and new sales systems born and above all it occurs a more efficient relationship between costs and incomes.

In the second half of the twentieth century, the conceptual elaboration that has most influenced the thinking on innovation of forms of distribution is, without doubt, the Theory of the wheel of retailing. This formulation is set on the assumption that, being the distribution structures a true product of the trade, it can extend to them the theory of the existence of a process of birth, growth and decline, not dissimilar from that is observed to the industrial goods.

The first contributions to this theory dates back to 1958 thanks to the studies of MP McNair; it was then formalized some years later thanks to the support of Hollander (1960).

The Theory of the wheel of retailing was been brought into question by scholars who have highlighted the limitations inherent in this approach. First of all, the first appearance of weakness highlighted is the role of businesses, if in the same form have the same type of conduct, although these are subjects autonomous in decisional chooses. In second place it is completely neglected the importance of the environment that is considered static and unchanging, in contrast to the systemic and constructivist theories that consider it subjected to the evolutionary dynamics. Then, the references to the reactions, that could have the competition in the moment in which it is stated on the market the new formula, are completely absent.

With the attempt to overcome the limitations described, it is developed the dialectical model, including the analysis of the competitors' reaction to entry in the market of a new formula.

The theory is substantiated by an interpretation of reality based on a cognitive tool borrowed by philosophical speculation. From two positions antithetical to each other (thesis and antithesis) can deduce consequences 
(synthesis) that does not properly belong to none of the starting position, according to the consolidated thought in philosophy. It is the mediation between opposites that generates the synthesis, in turn then intended to act as a target point to discuss because opposable of a further concept antithetical that will be generated. So this process is to be considered as a circular increasing (in terms of conceptual distance from the primary thesis) that improves the previous assumptions, overcoming the opposition and bringing out a positive result from the resolution of opposites. A significant advantage of this process is his unstoppable becoming by which the reality is always evolving and tending.

The retailers adapt its strategy to that of their competitors, following a temporal process that sees primarily the innovator in contrast to the present retail formulas (that represent the thesis); subsequently, by the arrangement generated by the interaction of both counterparties, the synthesis (new formula) arises, that in turn will be thesis for another antithesis and that, very soon, will converge towards a subsequent synthesis.

For complete analysis, including that it cites the model of the life cycle of Retail: similar to the theories for the product, Davidson, Bates and Bass (1976) considered worthwhile to assign to each retail formula a curve of lifecycle.

Probably the weakness of this theory consists in choosing the efficient cause: it cannot explain a phenomenon in the light of a single conditioning variable, nor it can believe there is a necessary relationship between the efficient cause (independent variable) and the effect (change of the sale formula). For this reason, none of the theories derived from this approach seems to have stood over the years to the criticism of scholars.

In an effort to broaden reference environment, such as to justify new formulas, multi-criteria models were born. They consider the evolution of the distribution formulas such as the result of the synergic action of several variables; these variables relate to features inside the formula itself, but also, and perhaps above all, to particular aspects of the external environment.

The latest theories that the retailer puts in place in order to systematize the vast amount of innovations - even at the micro level -have identified some macro-categories within which it implements innovation processes (Castaldo, Mauri, 2008):

\section{- Strategic \\ - Operational \\ - Relational}

The strategic dimension refers to innovations that affect store image perceived by consumers thanks to communication activities implemented by the company. For this purpose it is important to evaluate the impact that the innovative content of a format can have on the customer's perceptive dimension that allows him to categorize the format according to a certain kind of distribution.

The second level is the operating dimension refers to the more traditional methods of creating value in retailing, using the levers of the marketing mix: assortment, communication, environment sales and services, that are important elements of strengthening of the commercial offer.Acting on the operational dimension it can generate a particular attractiveness by developing strong relationships with consumers through a reshaping of the offer based on the needs identified.

The third level includes the innovative actions involving non-traditional areas of value creation but refer to the introduction of new instruments affecting the relational sphere helping to strengthen the relationship between the business enterprise and consumers. In particular, referring to the innovations in experiential shopping, in customer orientation with the participation of micro-marketing, in the e-tailing, that is the use of technological tools to establish a direct contact as well as interactive with consumers (Castaldo, Botti, 1999).

\subsection{Innovation Factors in Retail}

At this point it is useful to investigate the factors that induce retailers to innovate.

The reasons that induced the commercial enterprises to take an increasingly focus on innovation are varied but can be summarized in three main categories (Cardinali, 2009): environmental factors, factors of demand and factors of supply.

Environmental factors include changes in laws, economic, social and technological changes that have affected and still affect the commercial distribution sector.

Just think of the strong regulation to which they were subjected retailers before the introduction of the Bersani law that has helped create a real boost to trade freeing him from deep bureaucracy that characterized it. From the 
economic point of view we must consider the deep recession that the country is going through, with the consequent lowering of the income and the change in consumer purchases that have led many commercial enterprises to change their competitive strategies; Istat confirmed then a demographic shift due to an ageing of population and the growth of one-person households. From the technological point of view the development of innovations related to ICT (Information and communication technologies) that have influenced aspects of information management, processes, control systems, have further influenced the trading companies to exploit their potential.

Additional driver for retail's innovation concerns the demand factors and therefore the impact gave by consumption patterns and lifestyles on the purchasing behaviour of consumers. In particular, reference is made to the growing disloyalty to brands and products, the increased polarization of demand, the increase in unplanned purchases and the great importance given to the experience of purchase that led to the rise of experiential marketing whose biggest exponent are Pine and Gilmore (1999).

As stated previously, compared to mature markets, modernization and innovation of the retail impulses coming from macro and micro environment. The relevance in an innovative process of retail is generated on the basis of the action of common and integrated forces acting simultaneously in a local context. Assuming a subdivision in strands of literature reference, it is possible to identify at least five types of analyzes that consider the relationship between elements of the macro-micro-environment and processes to stimulate innovation (Bruni, 2014):

- Global crisis, economic difficulties and innovation the reference literature (Castaldo, 2008; Fornari, 2009 and Lugli, 2009) shows that in extreme uncertainty it can trigger the search for value by retailers by adapting their business model to the new needs of consumers through increased investment in various activities and marketing efforts.

- Changes in consumption and innovation; According to some authors (Shepherd, Pellegrini, Ravazzoni, 2001) the process of modernization of the distribution system is determined by changes in the structure of consumption and in buying patterns that have contributed to a cyclical evolution of demand for goods and commercial services; a fundamental role is exercised, then, by the economic crisis (Castaldo, 2008; Fornari, 2009; Lugli, 2009) that had an impact on three organizational areas of large retail: reports of trade marketing, decisions regarding the quantitative development of network, the declination of the levers of retail.

- Management organization development and innovation; considering the high level of competitiveness of enterprises of the distribution (Covin e Slevin, 1989), LSD changes his offer mainly through the reorganization of assortment for size distribution and the reinterpretation of format (Badot, 2000; Filser, 2002; Moati, 2001; Sansone, 2004); it is detected (Pepe and Musso, 2009) dynamism, wealth - in some cases - and flexibility of assortments of products and services, pursued three main directions: an intense rate of innovation, an articulated policy of private label products and a greater involvement with the local context.

- Search for new markets and innovation; some studies reported in the literature reference dealt with the relationship between business innovation of commercial distribution and the research of new market segments; some authors have analyzed the issue with reference to the role of regulation in the development of the performance of the retail market; others have dealt with the importance of the new format and concept in identifying new markets (Griffith and Harmgart, 2008) or enlargement of the services offered or organizational and interpersonal modality and management in general (Bell and Cuthbertson, 2004).

- Urban regeneration and innovation; In particular, the works on neighbourhood businesses studied the importance of economic activities in the city compared to the development of the economy and quality of life because of the stimulus to innovation and of influence on community cohesion (Coca-Stefaniak et al, 2005) on the wealth of the neighbourhood and the place, the diversity of choice for consumers.

\section{The New Concept of Proximity}

The issue of retail innovation is long been the subject of literature studies. Since 1976 it has developed a series of studies that have shown on the one hand that the weakening of local markets and the expansion of large stores and on the other hand the consumer perception that identified small neighbourhood shops as not comfortable, led to the decline of small retail, especially independent ones (Davies 1976; Dawson 2000; Dawson and Kirby 1979; Maroney 1976). This decline reduced the variety of formats and made less stable the local economy. The large stores were in fact usually located outside of the big cities: the choice of location outside the city was due on the 
one hand by the need to find suitable space to implant the new forms of distribution, and the other by the growing use of car in the private mobility that urban expansion-residential areas increasingly peripheral. The desertification of city centres caused in those years the closure of many businesses. The phenomenon of significant reduction of traditional stores led to obvious negative effects related to the reduction of local services and therefore a consequent weakening of the relational system.

In reference literature, very often the concept of proximity has been used for a comparison with large areas located off-city, arguing that consumers are willing to visit more distant store for an offer that recognizes an higher added value. Especially the reasons that over time have led consumers toward large retailers are summarized in socio-demographic causes such as the increasing of income per capita, young age, a good level of education and inadequate commercial structures local.

However in recent years this trend is being reversed and the data seem to support this thesis. It therefore speaks of a return to the vicinity of a trend in consumer to prefer proximity retail outlets than large distribution. The signals in this area are many and they are phenomena that are taking place in a very broad context that goes far beyond the Italian borders.

The concept of proximity and closeness has assumed a secondary role in the retail system, but it has evolved into new dimensions that go beyond purely spatial characteristics.

In fact, the recent literature in various scientific fields focuses on other types of proximity that you must consider integrated with each other, for a complete analysis (Bruni, 2014): Institutional (Kirat and Lung 1999), cultural (Gill and Butler 2003), organizational (Meisters and Werker 2004), social (Bradshaw, 2001), technological (Greunz 2003), cognitive (Nooteboom, 1999; 2000). In particular the prospect related to spatial proximity is no longer a necessary condition for the dissemination of knowledge; it can find it in organizational proximity, cognitive and cultural. It is emerging between scholars the concept of relational proximity that, in any case, is facilitated by the physical proximity between subjects. In the past the neighbourhood shops were those that guaranteed a high service of proximity and also provided for purchase in emergency. Today the term of "proximity" has a wider meaning: also a large store far from the consumer can be considered "proximity" if presents the characteristics of "relational proximity" with the consumer by establishing a long-term relationship of loyalty with it.

The reference literature has not dealt specifically the concept of "close relationship". The contributions about relationship marketing are numerous, but rarely these aspects are addressed organically and with reference to the concept of "spatial proximity" with the consumer. Trying to define the concept of "proximity relationship" it has to consider some areas of research, noting, in this regard, a gap in the study of the presence of many jobs that hardly have linked the need to satisfy the need for "emergency" the need for a short distance between the distributor and the consumer and the need to tighten a strong relationship with the customer. In literature there is no specific definition of the new proximity -"close relationship" - which stems from a strong stimulus to the strengthening of relations with the consumer, with the territory and with the 'company itself, and not from a regulatory approach, dimensional or space.

Ultimately, synthesizing the concepts just expressed it can be stated that the system of the elements of innovation in enterprises and the growing retail market mutations stimulates a relational approach between retailer and customer, as to bring out some features in the management of retail businesses that define the proximity "relational".

Through the study of literature reference it is possible to profile the characteristics of the "new proximity" and the factors that incentive to assess it.

The need of independent retailers or associated with large-scale distribution of to strengthen customer relationships and innovate their format and concept of sale, comes from some factors that pushed them to new ways of thinking about proximity.

These elements can be summarized as: economic difficulties and the global economic crisis, changes in consumption, competition, professional training; the influence of the media; generational change; influence of trade associations.

These factors led to the neighbourhood store to revisit their offer so that it was able to satisfy the needs of consumers and be more responsive to their needs.

This is how the new proximity store ensures greater quality of its products and a higher level of integrated services in order to survive to external changes. 
These stimulating factors were not only exogenous to the company but the need to change their characteristics has been felt from the inside: improved training and management of a planned strategy have allowed more openness to new things and opportunities that the external environment proposes.

The incentives arising from the external and innate characteristics of commercial enterprises have led the traditional retailers to innovate and invest in a set of tools that allow it to reposition itself on the market as well.

The predisposition to innovation by the small traditional retail stressed the importance of the recovery of central urban areas to small retail that there was not with the emergence of shopping centres in the extra-urban areas. In this sense it can speak of a "new proximity", for the innovative qualities that small traditional retail has than the past. Basically the new format of proximity are characterized by a high content of integrated services to the retail business, with a high quality of products and services, by a flexibility and continuous improvement in management, from attention to changing market conditions and the types of consumption, by investment in the development of the direct relationship and trust with customers, by enhancement of belonging to the territory and integration with the territorial government.

The "new proximity" takes on particular characteristics of supply and demand that affect each other in the same market; with the increased interest of LSD to proximity market it raises the level of competition in urban areas and it reduces the market for retail businesses not evolved and not innovative. The independent retailers have to find a solution for the development and adaptation; the LSD has to specialize itself in the proximity retailer. In particular in the European experience, there are several cases that show the interest of large scale distribution in investment in proximity format and the operation to support independent retailers in crisis: in the next section it will analyze a single case that appears to have the characteristics described.

\section{The Format of Relational Proximity: A Single Case Analysis}

In particular, the work focuses on the case of Coop.fi, a new format of proximity experienced by Coop Italy, cantered on the idea of a direct and personal relationship with partners and customers. The research provides a first level of analysis of the reasons that led the main Italian retail company to invest in this project, such as the main features and the results of this first period of activity. In particular the methodology implemented is the analysis of a case study (Yin, 2003), which is useful as an illustration and exemplification of what is described and as inspiration for the generation of new ideas in the field of retailing strategy, by implementing a research strategy of qualitative matrix in order to consider alsothe complexity of contexts and people(Gummesson, 2006).

The data analyzed were collected through a direct interview to the director of the store, through secondary data analysis and consultation of specialized magazines.

\subsection{The Case of Coop. $f i$}

In March 2015, Coop.fi has refurbished a supermarket in Grassina, near Florence, where there was a previous supermarket for 25 years, by launching a new concept that foreshadows a new "neighbourhood system", looking for a target, the elderly, that is becoming increasingly important. It is a store of 550 square meters where you can find crafts men: butcher, baker, and greengrocer, ready to offer some advice and recipes. The shop also hosts two corners with loose pet food and loose detergents. The two corners are almost connected and are located where the layout has been reduced to allow for quick shopping.

The location is in the village of Grassina and customers can go on foot or by car (underground parking for 25 cars is quite small), with some difficulty to leave the car, to induce consumers to reach the store preferably on foot or by bicycle. The income of the first isochronous of residents is medium high. The surface of the supermarket is 450 square meters on one level to form a large and irregular horseshoe. The sections form a square like in a local market.

The designers in developing the layout have considered two timing to do shopping: a longer and a quick shopping, by cutting off the gondolas in middle of the layout to allow a quick entrance to the counters. Gondolas have been lowered to 1.60 meters to allow to observe the perimeter and make ergonomic the access to the shelf and so the purchase of products; the price tags are more readable; refrigerators are closed to save energy; the shopping carts are produced with recycled plastic and the lights are led. The parquet floor made with stoneware with a pleasing effect mimics the essence of wood that merges with the equipment and with the wooden crates containing fresh produce.

At the top level it has opened a room of 100 square meters; it's an area dedicated to the sociality, where you can stop to read a book, a newspaper or just to rest.

The assortment has been reviewed in depth to give a size of extension acceptable: the scale was increased and 
prices around 500 local products have been introduced.

The shelves in front of counters have been renovated and now house instead of snacks and chewing gum only neutral products for children or natural snack.

In addition, the new format proximity promotes private label products (especially Fiorfiore Coop) highlighting the gap in price than industrial products: there are numerous red shelves that contain private label products and industrial brand product to allow a price comparison.

\subsection{Findings and Discussion}

The first goal is to understand what are the factors that have led Coop to invest in format Coop.fi. The analysis shows that the first reason why the firm Coop has decided to invest in a new concept of neighbourhood is the history and the social capital that characterizes it.

In fact, Coop states that those who work and who does the shopping in Cooperative knows that his commitment not need to enrich someone, but to improve conditions for members-citizens and leave a legacy helpful to future generations. Unicoop Firenze existed since 1973 and as all consumers cooperative it was created to defend the members of prices and quality of products.

So the first factor in stimulating of format innovation to the proximity relationship is the social base that characterizes the history of Coop that requires a return to the past: the Coop distributive chain was in fact characterized from the beginning by many small retail outlets. A further factor of encouragement of relational proximity is the strong local roots and awareness of the role that the retailing plays in the development of place and the local economy.

Secondly, the opening of the store was supported by market analysis showing the change of the consumers' lifestyle, the reduction of the time available to make purchases and the need to establish long-term relationships of loyalty with the retailer. Finally, another technical motivation is to have a ready structure suited to the project of "new proximity" of Coop.

The second objective of the research is to understand what are the key points of the marketing strategy at the bottom of new format of proximity. The management of Grassina highlights three key points: the management of the fresh foods, the relationship with the customer and the staff.

The category management and visual merchandising of the store are built with the aim to involve the customer in the typical atmosphere of a local market: in order to point especially to the everyday purchase, the main categories aimed at building a relationship of loyalty with the customer are those of fresh goods. Analysing the communication strategies implemented and the payoff it is clear that the goal pursued by Coop.fi is to become the "daily" shop of local stakeholders. The bakery department, for example, produces directly inside the store 48 different types of bread; one important change is the self-service shelf, where the customer has the ability to help himself and to choose the amount and quality desired. Just think that in this first period of activity, $90 \%$ of sales of bread and baked products inside the store consists of fresh foods prepared in store. Likewise also the meat department - considering the general trading down of consumption - registers positive performance.

Bread, meat and vegetables are excellent local products; the goal is to short the supply chain to ensure that the product that reaches the final consumer is fresher as possible. Sometimes it happens that customers await the arrival of in-store fresh goods just picked from local producers.

A particular choice, but coherent with what has been described on the category management concerns the fish department open only on Friday, to ensure to consumer the freshness of products.

As anticipated the core of marketing strategies of Coop.fi is the relationship with the customer, which is synthesized in the staff of front office, 23 people trained to meet the needs of customers. Once again, the goal is everyday life, to create a relationship of trust with the clerk of the store. At this early stage it seems that the objective has been achieved: in fact, surveys in store by management show that sometimes the customers "make a walk in the store" without need to shop only to greet workers or to remain in the social space.

Therefore the management declares very positive performance in this first period of activity both in terms of sales, both in terms of number of entries in the store, even by people that live outside the isochrones target.

\section{Conclusions}

The work highlights the innovative trends of retail enterprises and the new evolutionary models, with particular focus on a return to the concept of proximity, certainly not only physical, but trusty and relational. In particular, the case analyzed shows that the main Italian retailer has innovated its distributive offer toward a new format, with the 
purpose of establishing a relationship of loyalty with the consumer, and a everyday relationship between consumer and retailer. The main drivers of this strategy are the fresh goods' categories that daily convey quality and excellence of products - emphasizing local ones - and the front office staff, selected and trained in order to satisfy all customer needs and to establish with them relationships of real loyalty.

The analysis highlights the positive performance of the store and the ability of Coop to design a format that, thanks to its features and marketing tools, is replicable in other contexts, and it is be able to generate value even in other places.

However, the analysis carried out is still at an early stage and it is expected to implement further investigation through surveys in store and interviews with consumers.

\section{References}

Alexander, A., Phillips, S., \& Shaw, G. (2008). Retail innovation and shopping practices: Consumers' reactions to self-service retailing. Environment and Planning A, 40(9), 2204-2221. https://doi.org/10.1068/a39117

Badot, O. (2000). Devenir de la distribution. P. Joffre e S. Wickam (Eds), Colombelles Editions EMS, Le Marche' demain.

Bell, R., \& Cuthbertson, R. (2004). Collaboration in the retail supply chain. In Reynolds J. https://doi.org/10.1016/b978-0-7506-5696-2.50005-2

Bradshaw, M. (2001). Multiple proximities: culture e geography in the transport logistics of newsprint manufactured in Australia. Environment e Planning A, 33(10), 1717-1739. https://doi.org/10.1068/a33220

Bruni, R. (2014). Dinamiche impresa-contesto-cliente e retail di prossimità, Aracne Editore, Roma

Cardinali, M. G. (2009). Shopper Marketing, Egea, Milano.

Castaldo, S. (2008). Retail e channel management, Egea, Milano.

Castaldo, S., \& Botti, S. (1999). La dimensione emozionale dello shopping. Una ricerca esplorativa sul ruolo del punto di vendita. Economia \& Management, 1, 17-37.

Castaldo, S., \& Mauri, C. (2008). Innovazione, experience, partnership. Casi di innovazione nel retail. Franco Angeli, Milano.

Castaldo, S., \& Mauri, C. (2010). Store management. Il punto vendita come piattaforma relazionale, Franco Angeli, Milano.

Coca-Stefaniak, J. A., Parker, C., Barbany, A., Garrell, X., \& Segovia, E. (2005). Gran Centre Granollers - city, culture ecommerce. International Journal of Retail e Distribution Management, 33, 685-697. https://doi.org/10.1108/09590550510611878

Covin, J. G., \& Slevin, D. P. (1989). Strategic Management of Small Firm in Hosting e Bening Environments. Strategic Management Journal, 10. https://doi.org/10.1002/smj.4250100107

Cuthbertson, C., \& Bell, R. (2004). Retail strategy: the view from the bridge, Elsevier.

Cyert, R. M., \& March, J. G. (1963). A Behavioural Theory of the Firm, New Jersey, Prentice Hall

Davidson, W., Bates, R., Bass, A. D., \& Bass, S. J. (1976). The Retail life cycle. Harvard Business Review, November-Dicember, 89-96.

Davies, R. L. (1976). The recent history and problems of small shops and related small businesses. Local shops: Problems and prospects, eds Jones, P and Oliphant, R. Reading: URPI.

Dawson, J. (2000). Future patterns of retailing in Scotland. Development Department Research Programme Research Findings, 91, Scottish Executive: Edinburgh.

Dawson, J., \& Kirby, D. A. (1979). Small scale retailing in the UK: Saxon House, Farnborough.

Filser, M. (2002). Le Marketing de la production d'expérience: Statut theorique et implications manageriales. Décisions Marketing, 28.

Fornari, D. (2009). Tendenze distributive. Le nuove sfide del marketing di filiera, Egea, Milano.

Fornari, D. (2009). Trade marketing. Relazioni di filiera e strategie commerciali, Egea, Milano.

Gill, J., \& Butler, R. J. (2003). Managing instability in cross-cultural alliances. Long Range Planning, 36(6), 543-563. https://doi.org/10.1016/j.lrp.2003.08.008

Greunz, L. (2003). Geographically e technologically mediated knowledge spillovers between European regions. 
Annals of Regional Science, 37(4), 657-680. https://doi.org/10.1007/s00168-003-0131-3

Griffith, R., \& Harmgart, H. (2008). Supermarkets e Planning Regulation. CEPR Working Paper, 6713.

Gummesson, E. (2003). All research is interpretive. Journal of Business \& Industrial Marketing, 18(6-7), 482-492. https://doi.org/10.1108/08858620310492365

Hollander, S. C. (1960). The wheel of retailing. Journal of marketing, 7(24). https://doi.org/10.2307/1249121

Kirat, T., \& Lung, Y. (1999). Innovation and proximity - Territories as loci of collective learning processes. European Urban and Regional Studies, 6(1), 27-38. https://doi.org/10.1177/096977649900600103

Lugli, G. (2009). Il ruolo della politica assortimentale nella crisi e rilancio dell'ipermercato. Mercati $e$ Competitività, 3, 11-32.

Lugli, G. (2009). Marketing distributivo. La creazione di valore nella distribuzione specializzata, UTET, Torino.

Maroney, A. (1976). The decline of small shops in Liverpool and the problems involved in providing new facilities. Local shops: Problems and prospects, eds Jones, P and Oliphant, R. Reading, URPI.

Meisters, C., \& Werker, C. (2004). Physical and organizational proximity in territorial innovation systems: introduction to the special issue. Journal of Economic Geography, 4(1), 1-2. https://doi.org/10.1093/jeg/4.1.1

Moati, P. (2001). L'avenir de la gree distribution, Editions Odile Jacob, Paris.

Musso, F. (2010). Innovation in Marketing Channels: Relationships, Technology, Channel structure. Symphony: Emerging Issues in Management, 1, 23-42. https://doi.org/10.4468/2010.1.04musso

Nooteboom, B. (1999). Innovation e inter-firm linkages: new implications for policy. Research Policy, 28(8), 793-805. https://doi.org/10.1016/S0048-7333(99)00022-0

Nooteboom, B. (2000). Learning e Innovation in Organizations e Economies, Oxford, Oxford University Press.

Pastore, A., Pellegrini, L., \& Ravazzoni, R. (2001). La dimensione settoriale dell'innovazione: la distribuzione commercial. Sinergie-Rivista di Studi e Ricerche, 55.

Pepe, C., \& Musso, F. (2009). Piccoli produttori e grandi distributori: prospettive di sviluppo internazionale nei circuiti commerciali e logistici. Pepe C., Zucchella A. (ed.), Imprese e processi di internazionalizzazione, Il Mulino, Bologna, 127-155.

Pine, B. J., \& Gilmore, J. H. (1999). The Experience Economy. Work is theatre e every business a stage. Harvard Business School Press, Boston.

Quinn, B. (2013). Innovation in small-scale retailing: A future research agenda. International journal of entrepreneurship e innovation. https://doi.org/10.5367/ijei.2013.0111

Sansone, M. (2002). L'innovazione di format e di concept nella distribuzione commerciale al dettaglio. Congresso Internazionale Francia - Italia, Le tendenze del marketing in Europa.

Sansone, M. (2004). Le determinanti dell'innovazione nei moderni contesti distributivi. Nuove linee guida, schemi di pensiero ed osservazione di casi, ARACNE Editrice S.r.1., Roma.

Sansone, M. (2005). Il retailing: frequentazione del punto vendita, riconoscibilità dell'insegna e fidelizzazione del cliente nella moderna distribuzione, Baccarani Giappichelli Editore, Torino.

Sansone, M. (2006). Nuovi ambiti di ricerca nei moderni sistemi di scambio: focus sul marketing esperienziale. International marketing conference, University Ca' Foscari of Venice.

Schumpeter, J. A. (2002). Teoria dello sviluppo economico, ETAS, Milano

Yin, R. (1994). Case study research: Design and methods (2nd ed.). Thousand Oaks, CA: Sage Publishing.

Yin, R. (2003). Case study research: Design and methods (3rd ed.). Thousand Oaks, CA: Sage.

Dawson, J., \& Kirby, D. A. (1979). Small scale retailing in the UK: Saxon House, Farnborough.

Filser, M. (2002). Le Marketing de la production d'expérience: Statuttheoriqueet implications manageriales. Décisions Marketing, 28.

Fornari, D. (2009). Tendenze distributive.Le nuovesfidedel marketing di filiera, Egea, Milano.

Fornari, D. (2009). Trade marketing.Relazioni di filiera e strategiecommerciali, Egea, Milano.

Gill, J., \& Butler, R. J. (2003). Managing instability in cross-cultural alliances. Long Range Planning, 36(6), 
543-563. https://doi.org/10.1016/j.lrp.2003.08.008

Greunz, L. (2003). Geographically e technologically mediated knowledge spillovers between European regions. Annals of Regional Science, 37(4), 657-680.https://doi.org/10.1007/s00168-003-0131-3

Griffith, R., \& Harmgart, H. (2008). Supermarkets e Planning Regulation. CEPR Working Paper, 6713.

Gummesson, E. (2003). All research is interpretive. Journal of Business \& Industrial Marketing, 18(6-7), 482-492. https://doi.org/10.1108/08858620310492365

Hollander, S. C. (1960). The wheel of retailing. Journal of marketing, 7(24). https://doi.org/10.2307/1249121

Kirat, T., \& Lung, Y. (1999). Innovation and proximity - Territories as loci of collective learning processes. European Urban and Regional Studies, 6(1), 27-38. https://doi.org/10.1177/096977649900600103

Lugli, G. (2009). Ilruolodellapoliticaassortimentalenellacrisi e rilanciodell'ipermercato. Mercati e Competitività, $3,11-32$.

Lugli, G. (2009). Marketing distributivo. La creazione di valorenelladistribuzionespecializzata, UTET, Torino.

Maroney, A. (1976). The decline of small shops in Liverpool and the problems involved in providing new facilities. Local shops: Problems and prospects, eds Jones, P and Oliphant, R. Reading, URPI.

Meisters, C., \& Werker, C. (2004). Physical and organizational proximity in territorial innovation systems: introduction to the special issue. Journal of Economic Geography, 4(1), 1-2.

https://doi.org/10.1093/jeg/4.1.1

Moati, P. (2001). L'avenir de la gree distribution, Editions Odile Jacob, Paris.

Musso, F. (2010). Innovation in Marketing Channels: Relationships, Technology, Channel structure. Symphony: Emerging Issues in Management, 1, 23-42. https://doi.org/10.4468/2010.1.04musso

Nooteboom, B. (1999). Innovation e inter-firm linkages: new implications for policy. Research Policy, 28(8), 793-805. https://doi.org/10.1016/S0048-7333(99)00022-0

Nooteboom, B. (2000). Learning e Innovation in Organizations e Economies, Oxford, Oxford University Press.

Pastore, A., Pellegrini, L., \&Ravazzoni, R. (2001). La dimensionesettorialedell'innovazione: la distribuzionecommercial.Sinergie-Rivista di Studi e Ricerche, 55.

Pepe, C., \& Musso, F. (2009). Piccoliproduttori e grandidistributori: prospettive di sviluppointernazionaleneicircuiticommerciali e logistici. Pepe C., Zucchella A. (ed.), Imprese e processi di internazionalizzazione, Il Mulino, Bologna, 127-155.

Pine, B. J., \& Gilmore, J. H. (1999). The Experience Economy. Work is theatre e every business a stage. Harvard Business School Press, Boston.

Quinn, B. (2013). Innovation in small-scale retailing: A future research agenda. International journal of entrepreneurship e innovation. https://doi.org/10.5367/ijei.2013.0111

Sansone, M. (2002). L'innovazione di format e di concept nelladistribuzionecommerciale al dettaglio. CongressoInternazionaleFrancia - Italia, Le tendenzedel marketing in Europa.

Sansone, M. (2004). Le determinantidell'innovazioneneimodernicontestidistributivi.Nuovelineeguida, schemi di pensieroedosservazione di casi, ARACNE EditriceS.r.l., Roma.

Sansone, M. (2005). Il retailing: frequentazione del puntovendita, riconoscibilitàdell'insegna e fidelizzazione del clientenellamodernadistribuzione, BaccaraniGiappichelliEditore, Torino.

Sansone, M. (2006). Nuoviambiti di ricercaneimodernisistemi di scambio: focus sul marketing esperienziale. International marketing conference, University $\mathrm{Ca}$ ' Foscari of Venice.

Schumpeter, J. A. (2002). Teoria dello sviluppo economico, ETAS, Milano.

Yin, R. (1994). Case study research: Design and methods (2nd ed.). Thousand Oaks, CA: Sage Publishing.

Yin, R. (2003). Case study research: Design and methods (3rd ed.). Thousand Oaks, CA: Sage.

\section{Copyrights}

Copyright for this article is retained by the author(s), with first publication rights granted to the journal.

This is an open-access article distributed under the terms and conditions of the Creative Commons Attribution license (http://creativecommons.org/licenses/by/4.0/). 